\title{
Contents, Vol. 198, 1989
}

\section{Contents Vol. 198,1989}

No. 1 In memoriam 1

Original Paper $\cdot$ Travaux originaux $\cdot$ Originalarbeiten

Fusarium oxysporum Keratitis

Hemo, I.; Pe'er, J.; Polacheck, 1

Bilateral Macular Coloboma Associated with Progressive Atrophy of the

PeripheralRetinaFunada, M.; Okamoto, I.; Hayasaka, S 8

Bilateral Compressive Optic Neuropathy Secondary to Bilateral Sphenoethmoidal Mu-

cocelesNewton, N., Jr.; Baratham, G.; Sinniah, R.; Lim, A 13

Tear Protein Analyses in 30 Patients before and after Penetrating Keratoplasty

Lundh, R.L.; Engler, R 20

Cytology of Intraocular Lens Surface: A Transmission Electron-Microscopic Study. Cytology of Intraocular Lens SurfaceIshibashi, T.; Sugai, S.; Kubota, T.; Ohnishi, Y.; Inomata, H 30

Study of a New Series of Large Relaxing Retinotomies

Haut, J.; Monin, C; Larricart, P.; van Effenterre, G.; Piaton, J.M.; Flamand, M. . . 35

Neuroretinal Rim Area in Normal Eyes: A Study on a Randomized Group of 30SubjectsBottoni, F.G.; Gonnella, P.M.; Porta, A.S.; Consalez, G.G 40

Length-Tension Diagrams of Medial Rectus Muscles after Cupper's Fadenoperation. Surgical Assessment of the Reversibility of Posterior Fixation SuturesCastanera, A.M 46

Accuracy of Memory-Guided Saccades

Ohtsuka, K.; Sawa, M.; Takeda, M 53

No. 2 Original Paper · Travaux originaux — Originalarbeiten

Comparative Study of Argon Laser Trabeculoplasty in Primary Open-Angle and Pseudo-

exfoliation GlaucomaPsilas, K.; Prevezas, D.; Petroutsos, G.; Kitsos, G.; Katsougiannopoulos, V 57

Wirkung von Carteolol- und Timolol-Augentropfen auf die Drucktoleranz des Sehnerven-kopfes Stodtmeister, R.; Pillunat, L.; Wilmanns, I.; Neubrand, M.; Finger, B.; Tobias, G. . 64

Contents

III

Retinal Leakage in Retinal Vein Occlusion: Reduction after Hyperbaric Oxygen(With 1 color plate)Roy, M.; Bartow, W.; Ambrus, J.; Fauci, A.; Collier, B.; Titus, J 78

Intraocular Foreign Bodies. 297 Consecutive Cases

Behrens-Baumann, W.; Praetorius, G 84

Relations between Visual Acuity, Refraction and the Pattern Reversal Visual-Evoked Cortical

Potential in AphakiaMüller, W.; Schöneich, H 89

Clinical and Electrophysiological Abnormalities in the Visual System in Myotonic

DystrophyKerty, E.; Ganes, T 95

Clinicopathologic Case Report · Description clinico-pathologique de cas $\cdot$ Klinisch-

pathologische Fallbeschreíbung 
Metastasis of Bronchial Carcinoid Tumour to Choroid Balestrazzi, E.; di Tondo, U.; delle Noci, N.; Blasi, M.A 104 Announcement $\cdot$ Communication Ankündigung 109

Book Reviews — Livres nouveaux — Buchbesprechungen 110

No. 3 Original Paper $\cdot$ Travaux originaux $\cdot$ Originalarbeiten

Siderosis bulbi Induced by Intraocular Lens Implantation (With 1 color plate)

Yamaguchi, K.; Tamai, M 113

Course of Retinopathy in Children and Adolescents with Insulin-Dependent Diabetes mel-

litus: A Ten-Year Study

Cerutti, F.; Sacchetti, C; Vigo, A.; Dianzani, I.; Baratono, S.; Bessone, A.; Vaona, P.;

Furlotti, F 116

Successful Treatment of Metastatic Endophthalmitis. Case Reports

Wang, F.-D.; Wang, L.-S.; Liu, Y.-C; Liu, C.-Y.; Lin, C.-L.; Wong, W.-W 124

Assessment of Echographic Regression Criteria in Ruthenium-Irradiated Melanoma

Menapace, R.; Binder, W.; Skorpik, Ch.; Gnad, H.-D 129

Persistent Hyperplastic Primary Vitreous in the Right Eye and Congenital Grouped Pigmentation

of the Retina in the Left

Fujii, M.; Hayasaka, S.; Setogawa, T 135

Bilateral Anophthalmia and Unilateral Microphthalmia in Two Siblings

BenEzra, D.; Sela, M.; Peer, J140

Amount of Surgery in Congenital Nystagmus

D'Esposito, M.; Reccia, R.; Roberti, G.; Russo, P 145

Dry Eye before and after Therapy with Hydroxypropyl Methylcellulose. Ultrastructural and Cytochemical Study in 20 Patients

Versura, P.; Maltarello, M.C.; Stecher, F.; Caramazza, R.; Laschi, R

Clinicopathologic Case Report · Description clinico-pathologique de cas $\cdot$ Klinisch-

pathologische Fallbeschreibung

Corneal Carcinoma

Daxecker, F; Philipp, W.; Mikuz, G 163

Book Reviews - Livres nouveaux Buchbesprechungen 166

Announcements $\cdot$ Communications $\cdot$ Ankündigungen 168

IV

Contents

No. 4 Hypertensive Retinopathy

Introduction 173

Retinal Arteriolar Changes in Malignant Arterial Hypertension

Hayreh, S.S.; Servais, G.E.; Virdi, P.S 178

Cotton-Wool Spots (Inner Retinal Ischemic Spots) in Malignant Arterial Hypertension

Hayreh, S.S.; Servais, G.E.; Virdi, P.S 197

Retinal Lipid Deposits in Malignant Arterial Hypertension

Hayreh, S.S.; Servais, G.E.; Virdi, P.S 216

Macular Lesions in Malignant Arterial Hypertension

Hayreh, S.S.; Servais, G.E.; Virdi, P.S 230

Classification of Hypertensive Fundus Changes and Their Order of Appearance

Hayreh, S.S 247

Author Index 261 
Subject Index 262

S. Karger $\cdot$ Medical and Scientific Publishers

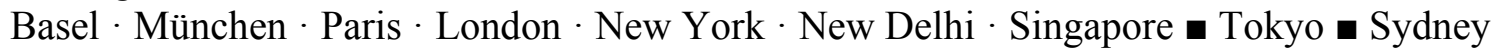

Drug Dosage All rights reserved.

The authors and the publisher have exerted every effort No part of this publication may be translated into otherto ensure that drug selection and dosage set forth in this languages, reproduced or utilized in any form or by anytext are in accord with current recommendations and means, electronic or mechanical, including photocopy-practice at the time of publication. However, in view of ing, recording, microcopying, or by any information stor-ongoing research, changes in government regulations, age and retrieval system, without permission in writingand the constant flow of information relating to drug from the publisher or, in the case of photocopying, directtherapy and drug reactions, the reader is urged to check payment of a specified fee to the Copyright Clearancethe package insert for each drug for any change in indica- Center (see 'Information for Readers and Subscribers'), tions and dosage and for added warnings and precautions. This is particularly important when the recom- (C) Copyright 1989 by

mended agent is a new and/or infrequently employed

S. Karger AG, P.O. Box, CH-4009 Basel (Switzerland)

drug. . Printed in Switzerland by

Buchdruckerei Friedrich Reinhardt AG

Basel 